\title{
Within-year nest reuse in open-nesting, solitary breeding passerines
}

\author{
Inge Hafstad ${ }^{1}$, Bård Gunnar Stokke ${ }^{1}$, Johan Reinert Vikan", \\ Jarkko Rutila², Eivin Røskaft ${ }^{1}$ \& Arne Moksnes ${ }^{1}$
}

Hafstad, I., Stokke, B.G., Vikan, J.R., Rutila, J., Røskaft, E. \& Moksnes, A. 2005. Within-year nest reuse in open-nesting, solitary breeding passerines. - Ornis Norvegica 28: 58-61.

During fieldwork at Lake Sic (46 $\left.57^{\prime} \mathrm{N}, 23^{\circ} 54^{\prime} \mathrm{E}\right)$, Romania, in the summer of 2003, we observed a strange incident of nest reuse in the Great Reed Warbler Acrocephalus arundinaceus. After first laying a complete clutch of five eggs and then ejecting an experimentally added parasite egg together with two of its own eggs, a new clutch was initiated in the same nest. In Tana $\left(70^{\circ} 16^{\prime} \mathrm{N}, 28^{\circ} 19^{\prime} \mathrm{E}\right)$, Norway, in June 2003 , we observed a similar incident in the Brambling Fringilla montifringilla. In a nest that was completely depredated when 3-4 eggs had been laid, a new clutch was initiated 8-9 days later. This is as far as we know the first time nest reuse has been documented in Great Reed Warblers and Bramblings.

Address: ${ }^{1}$ Department of Biology, Norwegian University of Science and Technology, NTNU, NO-7491 Trondheim, Norway; ${ }^{2}$ Department of Biology, University of Joensuu, FIN-80101 Joensuu, Finland

Corresponding author: Bård Gunnar Stokke, e-mail:bard.stokke@bio.ntnu.no

\section{INTRODUCTION}

Nest- or nest-site reuse is quite common in hole-breeding and colonially breeding birds (Lack 1954). However, among solitary breeding passerines building open nests, reuse of old nests is not a common strategy. This is particularly the case for within-year nest reuse. In this paper we report a case of within-year nest reuse in Romanian Great Reed Warblers Acrocephalus arundinaceus and a similar case in Norwegian Bramblings Fringilla montifringilla. Finally, we present a short review of such findings from other studies.

\section{RESULTS AND DISCUSSION}

\section{a) Nest reuse in Romanian Great Reed Warblers}

During fieldwork at Lake Sic (46 $\left.57^{\prime} \mathrm{N}, 23^{\circ} 54^{\prime} \mathrm{E}\right)$, Romania, in the summer of 2003, we observed a strange incident in a nest of the Great Reed Warbler. The study area at Lake Sic (21.4 ha) consisted of the littoral zone of the lake, which was made up mostly of reeds Phragmites australis and narrow-leaved cattail Typha angustifolia. Furthermore, the lake is surrounded by an open agricultural landscape mixed with patches of bushes and different species of willow Salix 
ssp. The Great Reed Warblers occupy the reedbed edge towards the water and Reed Warblers Acrocephalus scirpaceus dominate the rest of the reeds.

The Great Reed Warbler nest with the strange nest history was found on the 14 of May 2003. The nest was found 10 meters from the water edge and was attached to both reeds and narrow-leaved cattail. The nest contained one egg. The next days the Great Reed Warbler continued laying one egg each day and on the 18 of May the clutch was completed containing five eggs. All eggs were marked with a permanent marker in the order they were laid (1-5). We then placed a painted Chinese Quail Coturnix chinensis egg into the nest to observe the host reaction against this egg. This was according to standard procedure for the project, where the aim was study host adaptations against Common Cuckoo Cuculus canorus parasitism. On the 20 of May the Great Reed Warbler had ejected both the Quail egg and two of its own eggs, leaving three host eggs (marked 2,4 and 5) left in the nest. We then visited the nest several times the following days and on the 30 of May the Great Reed Warbler still incubated the three remaining eggs. The incubation time for this species is approximately 14 days (Cramp 1992) and the clutch should therefore have hatched on the 1 of June. However, when we visited the nest again on the 7 of June we observed to our surprise four eggs in the nest. The clutch consisted of three old and for sure infertile eggs (marked with numbers as described above) and one newly laid egg. The day after, on the 8 of June, another egg was laid and the clutch then consisted of five eggs. Unfortunately, we had to leave the study area on the 9 of June and thus we have no knowledge of the nest history after this date.

The nest had been visited at regular intervals during the breeding period, the eggs had been warm and the Great Reed Warbler present every time. This is a strong indication that it is the same pair that has incubated the clutch all along and then laid new eggs after a long incubation period.

\section{b) Nest reuse in Norwegian Bramblings}

During fieldwork in Tana (70 $\left.16^{\prime} \mathrm{N}, 28^{\circ} 19^{\prime} \mathrm{E}\right)$, Norway, in 2003, we recorded a peculiar breeding event in a nest of the Brambling. The study area in Tana, which was typical subalpine birch Betula ssp. forest, held a very high breeding density of Bramblings this year - probably a numerical response to a coincident mass occurrence of the geometrid moth Epirrita autumnata (see Hogstad 2000a, 2005).

The nest of interest was found completed but empty on the 6 of June 2003 in a birch $5 \mathrm{~m}$ above ground. On the following three days the Brambling laid one egg each day. On the 10 of June we found the nest emptied but otherwise well preserved; a hallmark of a visit paid by an avian nest predator (most likely a Hooded Crow Corvus cornix or a Magpie Pica pica). Expecting the female to follow common practice and build a new nest for her replacement clutch, we paid no further attention to the depredated nest during the next two weeks. On the 24 of June, when searching for nests in the vicinity of the predated nest, we were surprised to find a female incubating six eggs in the same nest that had been robbed 14 days earlier. By doing a floating test of the eggs (Hays \& LeCroy 1971), we were able to determine that the eggs had been incubated for 1 2 days. This means that, assuming that incubation starts with the penultimate egg, the new clutch was initiated on 18 or 19 of June; more than a week after the first clutch was depredated.

The total number of eggs laid in the focal nest was at least 9 or 10 eggs, which is extremely unlikely to be attained by a Brambling in one clutch (Cramp \& Perrins 1994, Hogstad 2000b, J. R. Vikan, J. Rutila, B. G. Stokke, A. Moksnes, E. Røskaft, unpublished data). Thus, we conclude that this is the first probable case of within-year nest-reuse described for an open-nesting, solitary breeding passerine in Norway. Unfortunately, we were unable to confirm whether the same individual laid both clutches. 
Four additional cases of potential reuse of a nest after depredation were observed in 2003. In all cases, the nest was depredated when it contained 2 or 3 eggs. However, the time between depredation and initiation of the «second» clutch was only 1-3 days and the total number of eggs laid per female was always within the normal clutch size of Bramblings (5-7). In this species, gaps in laying sequence of one clutch may occur during periods of harsh weather (Hogstad 2000b, J. R. Vikan, J. Rutila, B. G. Stokke, A. Moksnes, E. Røskaft, unpublished data), and may last for up to five days (Hogstad 2000b). Thus, it is unclear whether these incidents are real cases of nest reuse or gaps in the laying sequence of a single clutch. The real number of incidents might well have been higher; since only a small subset of the depredated nests were revisited (the predation rate was 102/217).

\section{c) Review of other records}

Usually, passerines like Great Reed Warblers and Bramblings build a new nest before relaying a clutch. However, there exist a few documented cases of nest reuse. Warden (2003) reports one instance of nest reuse after fledging the first brood in a study on Reed Warblers in England. Furthermore, Westwood (2005) reports two instances of relaying without refurbishment in Reed Warbler nests that had previously been depredated. Reed Warblers may also bury one or more conspecific eggs and lay a new clutch on top of the old eggs. Thus, in the Danube delta, Romania we found one clutch that contained five eggs that were buried in the nest lining below five fresh eggs (I. Hafstad, B. G. Stokke, A. Moksnes \& E. Røskaft, unpubl. data). It is also known that this species sometimes build a new nest on top of the old one (e.g. Borowiec 1992; Ritter \& Ritter 2002; Herschmann 2003, Westwood 2005, I. Hafstad, B. G. Stokke, A. Moksnes \& E. Røskaft, unpubl. data), or refurbish old successful nests (Westwood 2005). Furthermore, it is known that some host species of brood parasites occasionally bury the parasite egg and lay new eggs on top of the old nest contents (Friedmann 1963, Wyllie 1981,
Sealy 1995, Nakamura et al. 1998, A. Antonov, B. G. Stokke, A. Moksnes \& E. Røskaft, unpubl. data). In Great Reed Warblers such behaviour is typically recorded if the Cuckoo egg is laid before initiation of host egg-laying (Moskát \& Honza 2002, but see Molnár 1944). However, also other objects than eggs that are added to Great Reed Warbler clutches will often be buried in the host pre-laying period (Bártol et al. 2003). In other hosts, the parasite egg can be buried also after own clutch initiation so that both parasite- and host eggs will be buried together, and in the North American Yellow Warbler Dendroica petechia egg-burial is the main method of rejection of parasite eggs regardless of the stage in the breeding period (Sealy 1995).

There also exist a few reports of within-year nest reuse in other open-nesting, solitary breeding passerines. Andrzej Dyrcz reports of two cases in Clay-coloured Robins Turdus grayi in Panama where the second brood was raised in the same nest as the first successful one. In one of these cases, the female was colour-ringed and he was able to ascertain that the same bird took part in two consecutive broods (Dyrcz 1983). Friesen et al. (1999) found two instances of within-year nest reuse in another Turdidae, the North American Wood Thrush Hylocichla mustelina. All four nesting attempts resulted in successfully fledged young. In Arizona, one single colour-banded Willow Flycatcher Empidonax traillii female reused nests with varying success within-year in two consecutive years (Yard \& Brown 1999). Finally, there are a few reports of within-season nest reuse in three additional North American open-nesting, solitary breeding passerines; Field Sparrow Spizella pusilla, Western Kingbird Tyrannus verticalis and Brown Thrasher Toxostoma rufum (Hunter 1905, Nicholson 1981, Cavitt et al. 1999).

To sum up, in this paper we report the first cases of nest reuse in Great Reed Warblers and Bramblings. Furthermore, the instance of Great Reed Warbler nest reuse is unique in that the new clutch was laid without burying or removing the old clutch of probably infertile eggs. 


\section{ACKNOWLEDGEMENTS}

Thanks to Andrzej Dyrcz and Karl SchulzeHagen for providing literature and comments, and to Istvan Kovacs and Peter Pap for participation in the field work. Thanks are also due to Olav Hogstad and one anonymous referee for useful comments.

\section{SAMMENDRAG}

\section{Gjenbruk av reir innen hekkesesongen hos solitært hekkende spurvefugler med åpne reir}

Under feltarbeid ved Lake Sic ( $\left.46^{\circ} 57^{\prime} \mathrm{N}, 23^{\circ} 54^{\prime} \mathrm{E}\right)$, Romania, sommeren 2003, observerte vi et usedvanlig tilfelle av eggomlegging $i$ et tidligere benyttet reir hos trostesanger Acrocephalus arundinaceus. Etter først å ha lagt ferdig et kull på fem egg og deretter kastet ut et eksperimentelt tilført parasittegg og to egne egg, ble et nytt kull initiert i det samme reiret. Under feltarbeid i Tana $\left(70^{\circ} 16^{\prime} \mathrm{N}, 28^{\circ} 19^{\prime} \mathrm{E}\right)$, Norge, i juni 2003 , observerte vi et liknende tilfelle hos bjørkefink Fringilla montifringilla. I et reir som ble fullstendig predatert etter at 3-4 egg var lagt, ble det påbegynt et nytt kull 8-9 dager senere. Dette er så vidt vi vet første gang gjenbruk av reir er dokumentert hos trostesanger og bjørkefink.

\section{REFERENCES}

Bártol,I., Moskát, C., Karcza,Z. \& Kisbenedek, T. 2003. Great reed warblers bury artificial objects, not only cuckoo eggs.- Acta Zoologica Academiae Scientiarum Hungaricae 49: 111-114.

Borowiec, M. 1992. Breeding ethology and ecology of the reed warbler Acrocephalus scirpaceus at Milicz, SW Poland. - Acta Zoologica Cracoviensia 35: 315-350.

Cavitt, J. F., Pearse, A. T. \& Miller, T. A. 1999. Brown thrasher nest reuse: a time saving resource, protection from search-strategy predators, or cues for nest-site selection? - Condor 101: 859-862.

Cramp, S.(ed.). 1992. The birds of the Western Palearctic, Vol. VI. Oxford University Press, Oxford.
Cramp, S. \& Perrins, C. M. (eds.). 1994. The birds of the Western Palearctic, Vol. VIII. Oxford University Press, Oxford.

Dyrcz, A. 1983. Breeding ecology of the clay-coloured robin Turdus grayi in lowland Panama. - Ibis 125: 287-304.

Friedmann, H. 1963. Host relations of the parasitic cowbirds. Smithsonian Institution, United States National Museum Bulletin 233, Washington D.C.

Friesen, L.E., Wyatt, V.E.\& Cadman,M.D. 1999. Nest reuse by wood thrushes and rose-breasted grosbeaks. - Wilson Bulletin 111: 132-133.

Herschmann, W. 2003. Ein «Doppelnest» beim Teichrohrsänger. - Der Falke 50: 189.

Hays, H. \& LeCroy, M. 1971. Field criteria for determining incubation stage in eggs of the common tern. - Wilson Bulletin 83: 425-429.

Hogstad, O. 2000a. Fluctuation of a breeding population of brambling Fringilla montifringilla during 33 years in a subalpine birch forest. - Ornis Fennica 77: 97-103.

Hogstad, O. 2000b. Bjørkefink - en karakterart for fjellbjørkeskogen. - Vår Fuglefauna 23: 152-161.

Hogstad, O. 2005. Numerical and functional responses of breeding passerine species to mass occurrence of geometrid caterpillars in a subalpine birch forest: a 30-year study. - Ibis 147: 77-91.

Hunter, J. S. 1905. Double nest of Arkansas kingbird. - Condor 7: 53.

Lack, D. 1954. The natural regulation of animal numbers. Clarendon Press, Oxford.

Molnár, B. 1944. The cuckoo in the Hungarian plain. - Aquila 51: 100-112.

Moskát, C. \& Honza, M. 2002. European cuckoo Cuculus canorus parasitism and host's rejection behaviour in a heavily parasitized great reed warbler Acrocephalus arundinaceus population. - Ibis 144: 614-622.

Nakamura, H., Kubota, S. \& Suzuki, R. 1998. Coevolution between the common cuckoo and its major hosts in Japan. Pp. 94-112 in Parasitic birds and their hosts (Rothstein, S. I. \& Robinson, S. K., Eds.). Oxford University Press, New York.

Nicholson, C. P. 1981. Likely nest reuse by a field sparrow. - Journal of Field Ornithology 52: 235.

Ritter, H. \& Ritter, A. 2002. «Doppelnest» beim Teichrohrsänger. - Der Falke 49: 119.

Sealy, S. G. 1995. Burial of cowbird eggs by parasitized yellow warblers: an empirical and experimental study. - Animal Behaviour 49: 877-889.

Warden, D. 2003. Reed warblers reusing nests. - British Birds 96: 303.

Westwood, N. J. 2005. Reed warblers reusing nests. - British Birds 98: 101.

Wyllie, I. 1981. The cuckoo. Batsford, London.

Yard, H.K. \& Brown, B. T. 1999. Willow flycatcher nest reuse in Arizona. - Journal of Field Ornithology $70: 211-213$. 